\begin{tabular}{ccc|}
\hline $\begin{array}{c}\text { JURNAL } \\
\text { INOVASI }\end{array}$ & $\begin{array}{c}\text { Jurnal Inovasi Teknologi Pendidikan } \\
\text { TEKNOLOGI } \\
\text { PENDIDIKAN }\end{array}$ & Volume 5, No 1, April 2018 (1-11) \\
Online: http://journal.uny.ac.id/index.php/jitp & $\begin{array}{c}\text { Ilkatan Profesi Teknologi } \\
\text { Pendidikan Indonesia }\end{array}$ \\
\hline \hline
\end{tabular}

\title{
PENGEMBANGAN E-LEARNING BERBASIS MOODLE DALAM PENINGKATKAN PEMAHAMAN LAGU PADA PEMBELAJARAN BAHASA INGGRIS
}

\author{
Randy Irawan ${ }^{1 *}$, Herman Dwi Surjono ${ }^{2}$ \\ 1STIT Ibnu Rusyd Grogot Paser, Kalimantan Timur \\ 2Universitas Negeri Yogyakarta \\ 1Jl. Negara Tanah Periuk, Tanah Grogot, Paser Kalimantan Timur Indonesia \\ 1J1. Colombo No. 1, Depok, Sleman 55281, Yogyakarta, Indonesia \\ * Corresponding Author. Email: elraenzio00@gmail.com
}

\begin{abstract}
Abstrak
Penelitian ini bertujuan untuk: (1) menghasilkan produk e-learning bahasa Inggris berbasis Moodle yang layak dalam peningkatan listening skill pada pembelajaran bahasa Inggris untuk SMK Negeri 4 Yogyakarta (2) mengetahui seberapa efektif e-learning berbasis Moodle terhadap listening skill pembelajaran bahasa Inggris siswa kelas X SMK Negeri 4 Yogyakarta. Jenis penelitian ini adalah $\mathrm{R} \& \mathrm{D}$ atau research and development menggunakan model Alessi \& Trollip melalui tiga langkah berikut: planning, design, dan development. Subjek Penelitian ini adalah siswa SMK Negeri 4 Yogyakarta. Tenik pengumpulan data yang digunakan yaitu wawancara, angket, dan tes. Hasil penelitian ini adalah sebagai berikut. (1) Produk e-learning dikembangkan dengan sebuah Learning Management System (LMS) online yang dibuat dengan software aplikasi Moodle versi 3.1. (2) Produk e-learning berbasis Moodle telah memenuhi kriteria dan dinyatakan layak sebagai media pembelajaran berdasarkan validasi ahli media dengan skor 3,70 dengan kriteria "Baik", berdasarkan validasi ahli materi dengan rerata skor 4,34 dengan kriteria "Sangat baik", dan berdasarkan respon pengguna dengan skor 4,30 dengan kriteria "Sangat baik". (3) Hasil belajar siswa kelas X UPW 2 SMK Negeri 4 Yogyakarta mengalami peningkatan setelah menggunakan e-learning. Keefektifan produk terhadap pembelajaran bahasa Inggris pada kompetensi listening dibuktikan melalui peningkatan hasil belajar yang diketahui dari persentase hasil evaluasi pretest dan posttest yakni sebesar $17,19 \%$.
\end{abstract}

Kata kunci: e-learning, listening, bahasa Inggris

\section{DEVELOPING AN E-LEARNING PRODUCT BASED ON MOODLE FOR INCREASING SONG COMPREHENSION IN TEACHING ENGLISH}

\begin{abstract}
This study aims to: (1) produce e-learning based on Moodle English viable in increasing listening skills in Teaching English for SMK Negeri 4 Yogyakarta (2) determine how effective E-learning based Moodle on listening skills in Teaching English for students class X SMK Negeri 4 Yogyakarta. The result are as follows. (1) The E-learning product was developed with a learning management system (LMS) online software applications created with Moodle version 3.1. (2) The e-learning based on Moodle is appropriate as a medium of learning based on the judgement from media experts with the feasibility mean score of 3.70 (good category), judgement from material experts with the feasibility mean score of 4.34 (very good category) and judgement from user with the feasibility mean score of 4.30 (very good category). (3) The learning achievement of class X UPW 2 students of SMK Negeri 4 Yogyakarta increases after the use of the e-learning product. The effectiveness of the product to learning English in listening competence demonstrated through learning outcome is known of the percentage of pretest and posttest evaluation results which amounted to $17.19 \%$.
\end{abstract}

Keywords: e-learning, listening, English

Permalink/DOI: http://dx.doi.org/10.21831/jitp.v5i1.10599 


\section{Pendahuluan}

Dewasa ini bahasa Inggris menjadi salah satu mata pelajaran yang wajib dipelajari, mulai dari tingkat SMP, SMA, SMK dan sampai perguruan tinggi. Di tingkat sekolah menegah bahasa Inggris ialah mata pelajaran yang diujikan secara nasional, hal ini membuat bahasa Inggris menjadi suatu keharusan untuk dikuasai bagi setiap orang, selain itu bahasa Inggris merupakan bahasa internasional, karena sebagian besar negara-negara di dunia menggunakan bahasa Inggris.

Dalam pembelajaran bahasa Inggris dikenal empat kompetensi skill yakni reading, speaking, writing dan listening. Dalam pembelajaran bahasa Inggris reading bertujuan agar peserta didik mampu memahami berbagai makna dalam teks tulis. Kemudian speaking bertujuan agar peserta didik memiliki kemampuan mengungkapkan berbagai makna melalui berbagai teks lisan, struktur teks dan linguistik tertentu. Adapun writing bertujuan agar peserta didik mampu mengungkapkan berbagai makna teks tulis yang memiliki tujuan komunikatif. Sedangkan listening berartujuan agar peserta didik mampu memahami berbagai makna (antar peseorangan, pendapat, buku pelajaran) berbagai teks lisan yang memiliki tujuan komunikatif, struktur teks dan linguistik tertentu.

Tujuan dari pembelajaran bahasa Inggris sendiri adalah agar mempersiapkan generasi muda Indonesia untuk dapat bersaing secara global, menurut Banasuru (2013, p. 101) bahasa merupakan salah satu sarana berpikir ilmiah, kemampuan berbahasa yang dimiliki akan membantu berpikir ilmiah, sisitematis dan teratur. Bahasa dipergunakan pada sebagian besar aktivitas manusia, tanpa bahasa manusia tidak dapat mengungkapkan perasaannya, menyampaikan keinginan, memberikan saran dan pendapat, bahkan sampai tingkat pemikiran seseorang yang berkaitan dengan bahasa. Semakin tinggi tingkat penguasaan bahasa seseorang, semakin baik pula penggunaan bahasa dalam berkomunikasi.
Masih terdapat banyak peserta didik yang menemukan kesulitan untuk mengekspresikan ide-idenya menggunakan bahasa Inggris, seperti yang disampaikan Iskandarwassid \& Sunendar (2015, p. 94) kesulitan yang terjadi bisa bersumber dari individu seperti, pola bahasa dan seringnya penggunaan bahasa daerah. Pola bahasa Inggris yang berbeda dengan bahasa Indonesia memang menjadi sebuah kesulitan tersediri bagi peserta didik, apalagi jika peserta didik dalam kesehariannya menggunakan bahasa daerah, ini tentu menambah kesulitan dalam pemahaman berbahasa asing. Kesulitan yang selanjutnya bersumber dari pembelajaran bahasa inggris, menurut Riyanto (2015, p. 6) menganalisis faktor-faktor yang mempengaruhi kesulitan tersebut menjadi sebagai berikut : (a) teknik mengajar yang kemudian menentukan minat, kreativitas dan hasil belajar siswa (b) kompetensi guru bahasa inggris. Untuk itu kompetensi dan inovasi dari seorang guru diharapkan mampu mengatasi kesulitan dalam pembelajaran, dengan pesatnya perkembangan teknologi guru memiliki berbagai alternatif dalam pembelajaran untuk tercapainya hasil belajar yang maksimal.

Selain permasalahan tersebut, ada beberapa masalah yang lebih spesifik seperti yang terjadi di SMKN 4 Yogyakarta. SMK Negeri 4 Yogyakarta adalah SMK berbasis pariwisata yang memiliki tujuh jurusan pariwisata. Diantara ketujuh jurusan tersebut jurusan Usaha Perjalanan Wisata ialah salah satu jurusan yang diharapkan memiliki keterampilan berbahasa dengan baik.

Namun dari hasil observasi di SMKN 4 Yogyakarta pada jurusan Usaha Perjalanan Wisata, ditemukan beberapa kesulitan dan kendala dalam pembelajaran bahasa Inggris terutama dalam penguasaan terhadap kompetensi skill listening yang masih kurang dikuasai oleh peserta didik, hal tersebut terlihat dari hasil ujian bahasa Inggris semester I dan dari hasil analisis kebutuhan dimana dari empat kompetensi skill bahasa Inggris speaking dan listening menjadi kompetensi yang susah untuk 
dikuasai, kesulitan tersebut dalam hal menangkap makna dan informasi dari materi listening yang diperdengarkan. Sedangkan jurusan Usaha Perjalanan Wisata kompetensi speaking dan listening menjadi sebuah skill yang wajib dikuasai guna mendukung komunikasi dalam berbahasa Inggris di dunia kerja nantinya. Selain itu kurangnya jam pelajaran bahasa Inggris serta banyaknya materi bahasa Inggris menjadi masalah dalam proses pembelajaran, sehingga perlunya pengunaan media pembelajaran yang bersifat mandiri untuk menunjang pembelajaran sehingga peserta didik dapat terus mengasah skill berbahasa Inggris baik di sekolah maupun di luar sekolah. Oleh sebab penguasaan skill berbahasa Inggris terutama pada aspek receptive skill yaitu speaking dan listening menjadi penting untuk diaplikasikan sebab kompetensi ini menuntut kreatifitas dan sarana pendukung seperti, laboratoruim bahasa, tape recorder, headsheet, kaset, CD pembelajaran dan lainnya.

Dalam beberapa penelitian terdahulu receptive skill dapat ditingkatkan dengan melatih kemampuan listening, karena sebagian besar aktivitas komunikasi manusia berawal dari aktivitas listening. Menurut Renukadevi (2014, p. 60) bahwa orang yang melakukan aktivitas listening bahasa Inggris dalam kehidupan sehari-harinya maka semakin baik pula tingkat kemahirannya dalam listening bahasa Inggris tersebut. Hal ini ditunjukkan dengan peningkatan kemampuan skill lain seperti peningkatantan skill speaking sebanyak 30\%, 15\% reading dan writing $10 \%$. Temuan ini sekaligus juga memberikan bukti yang kuat bahwa aktivitas menyimak bahasa asing mempunyai korelasi (hubungan) yang positif dengan kemahiran (prestasi) berbahasa asing. Selain itu bahwa pemahaman yang tinggi pada bahasa yang dipelajari dalam aspek yang lebih menyeluruh baik melalui membaca dan menyimak akan membantu proses pembelajaran, yang pada gilirannya akan meningkatkan kemahiran receptive skill berbahasa peserta didik pada umumnya.

Dari hasil analisis kebutuhan bahwa peserta didik menginginkan metode pem- belajaran yang berbeda dalam pembelajaran bahasa Inggris, sehingga kemampuan berbahasa Inggris mereka menjadi meningkat terutama pada kompetensi listening dan speaking, selain itu para peserta didik juga mengharapkan pemanfaatan lab komputer yang belum maksimal difungsikan, karena seiring pesatnya teknologi peserta didik lebih terbiasa belajar menggunakan komputer. Sedangkan analisis kebutuhan yang dilakukan kepada guru bahwa guru mengharapkan adanya media yang dapat dilakukan secara flexible untuk mengatasi masalah dalam pembelajaran, mengingat jam pelajaran bahasa Inggris hanya 2 jam pelajaran dalam seminggu, khusus untuk listening dan speaking menjadi kompetensi yang difokuskan guru bahasa Inggris untuk jurusan Usaha Perjalanan Wisata, agar output lulusan jurusan tersebut dapat berkomunikasi secara lisan di dunia kerja nantinya.

Munculnya internet dalam pendidikan membawa harapan baru, saat ini internet juga telah digunakan untuk membangun jaringan pendidikan. Pembelajaran dengan memanfaatkan internet terus berkembang pesat, hingga pada tahun 1970-an muncul istilah e-learning. E-learning terdiri dari dua bagian yaitu " $\mathrm{e}$ " yeng merupakan singkatan dari 'elektronik' dan 'learning' yang berarti pembelajaran. Menurut Glossry (Darmawan, 2014, p. 62): e-learning adalah sistem pendidikan yang menggunakan aplikasi elektronik untuk mendukung belajar mengajar dengan media internet, jaringan komputer, maupun komputer stand alone. Dengan e-learning proses pembelajaran diharapkan akan lebih dapat meningkatkan hasil belajar peserta didik.

Sejalan dengan hal tersebut, tempat penelitian yakni SMK Negeri 4 Yogyakarya telah memiliki laboratorium komputer serta telah memiliki fasilitas internet, sehingga hal tersebut mendukung pengembangan $e$ learning di SMK Negeri 4 Yogyakarta. Para peserta didik juga telah terbiasa menggunakan komputer dan internet, bahkan beberapa diantara mereka terbiasa membawa laptop ke sekolah, jadi akan lebih baik jika hal tersebut diarahkan pada proses pem- 
belajaran, siswa juga lebih antusias dalam proses pembelajaran mengunakan komputer dan internet. Sebagaimana hasil penelitian yang disampaikan Chen (2013, p. 178) bahwa penggunaan teknologi dan pengalaman sosial dapat meningkatkan hasil belajar peserta didik dalam belajar bahasa. Berdasarkan beberapa uraian diatas diperoleh asumsi bahwa dengan e-learning beberapa permasalahan pembelajaran diatas dapat diatasi khususnya dari segi efektivitas dan meningkatkan hasil pembelajaran kompetensi skill listening.

Salah satu pemanfaatan internet adalah pada sistem pembelajaran secara elektronik atau yang lebih dikenal dengan istilah e-learning. Menurut Rosenberg (2001, p. 15) e-learning merujuk pada penggunaan teknologi internet untuk mengirimkan serangkaian solusi yang dapat meningkatkan pengetahuan dan keterampilan. Menurut Clark \& Mayer (2008, p. 10) e-learning didefinisikan sebagai berikut :"e-learning is instruction delivered on a computer by way of CD-ROM, Internet, or intranet"

Sedangkan menurut Horton (2001, p. 1) "E-learning is the use of electronic technologies to create learning experiences". Berdasarkan definisi tersebut, dapat diperoleh asumsi bahwa e-learning dibuat agar pembelajaran dapaberbgt lebih terbuka dengan berbagai cara seperti merumuskan, mengorganisir, dan menciptakan pengalaman belajar yang lebih bebas, pembelajaran elektronik juga bertujuan keberhasilan pembelajaran, dimana didalamnya terdiri dari kombinasi elemen-elemen antara informasi, interaksi dan komunikasi pendidikan.

Setelah mengetahui beberapa definisi e-learning selajutnya terdapat banyak sekali Learning Managemen System pengelola web e-learning. Salah satu Learning Management System (LMS) tersebut ialah Moodle, rata-rata orang yang berkecimpung dalam bidang e-learning khususnya dari bidang pendidikan, psikologi, serta ilmu komputer mengenal Moodle. Moodle sendiri merupakan singkatan dari Modular Object-Oriented Dynamic Learning Environment. Learning
Management System (LMS) ini merupakan salah satu LMS papan atas.

Moodle adalah sebuah nama untuk sebuah program aplikasi yang lengkap yang dapat merubah sebuah media pembelajaran ke dalam bentuk web. Sebagaimana yang di jelaskan Jati (2013, p. 283) bahwa Moodle adalah suatu perangkat yang canggih untuk membuat dan mengelola kursus, mengecek kehadiran dan kinerja siswa, mengelola kuis dan tugas serta survei.

Ada beberapa alasan kuat, sehingga menjadikan Moodle sebagai salah satu LMS yang populer digunakan oleh banyak intitusi pendidikan, menurut Darmawan (2014, p. 70) ada empat alasan kuat, antara lain alasan yang pertama ialah Free dan open source, Moodle adalah LMS open source, sehingga dengan demikian semua orang dapat memodifikasinya sesuai dengan kebutuhan dari intitusi yang menggunakannya. Moodle didistribusikan secara gratis, sehingga tidak membutuhkan sedikitpun dana untuk membeli aplikasi ini, kecuali dana yang dibutuhkan unruk membeli bandwidth yang terpakai untuk mendownload $17 \mathrm{MB}$ master Moodle.

Alasan yang kedua, dilandasi oleh educational philosophy, Moodle dibangun berdasarkan pengalaman langsung di lapangan dengan latar belakang ilmu pendidikan. Sehingga Moodle mampu mengakomodir hampir semua kebutuhan pendidikan konvensional yang ditransfer dalam wujud online learning. Alasan yang ketiga, mempunyai komunitas yang besar dan saling berbagi. Komunitas pengguna Moodle tergabung dalam suatu organisasi www.moodle.org. Disana setiap pengguna Moodle dapat saling berbagi kebermanfaatan dan kendala dalam penggunaan Moodle. Alasan yang keempat ialah, ukuran kecil, kemampuan maksimal. Dengan ukuran yang kecil (hanya sekitar $17 \mathrm{MB}$ untuk versi Moodle 3.1) namun mampu mengelola aktifitas kegiatan akademik dan pembelajaran hingga seukuran sebuah universitas.

Selain pada sisi e-learning pengembang juga perlu mempertimbangkan $e$ learning dari sisi konten. Setidaknya ada 
enam prinsip yang harus diperhatikan menurut Mayer (2009) berkaitan dengan elemen media yang digunakan agar sebuah program e-learning berlangsung efektif. Keenam prinsip menyangkut elemen media dalam e-learning yang merupakan dasardasar mengembangkan media dalam $e$ learning. Pengembangan media yang dimaksud di sini menyangkut kombinasi teks, grafik, animasi dan suara untuk menyampaikan materi pembelajaran. Keenam prinsip tersebut adalah: (1) prinsip keterdekatan ruang: fokus utama pada prinsip ini ialah, penyajian materi multimedia akan lebih baik ketika kata-kata dan gambar-gambar terkait disajikan saling berdekatan Mayer (2009, p. 119). Dengan menyajikan kata-kata dan gambar-gambar saling berdekatan maka akan memudahkan peserta didik dalam menangkap dan menyimpan memori pesan tersebut. Implikasi prinsip ini pada e-learning nantinya pada sajian materi yang memberikan kedekatan posisi teks dan grafik yang relevan sehingga mudah dipahami oleh pengguna; (2) prinsip kedekatan waktu: fokus utama pada prinsip ini ialah menempatkan kata-kata dan gambar-gambar secara bersamaan (Mayer, 2009,p. 141). Implikasi prinsip ini pada e-learning ialah dengan menyajikan bersamaan posisi teks dan grafik yang relevan sehingga mudah dipahami oleh pengguna; (3) Prinsip Modalitas: Prinsip ini menjelaskan bahwa penggunaan animasi dan narasi dapat meningkatkan kegiatan belajar Mayer (2009, p. 197). Implikasi prinsip ini pada e-learning dengan menyajikan video di dalam e-learning, karena pesan multimedia dari video merupakan teks yang terucapkan sehingga akan lebih mudah dipahami. (4) Prinsip Redundansi: Prinsip ini menjelaskan bahwa peserta didik dapat belajar lebih baik dari animasi dan narasi dibandingkan animasi, narasi dan teks Mayer (2009, p. 215). Implikasi prinsip ini pada e-learning ialah dengan menyajikan materi dengan animasi dan narasi dalam bentuk video. (5) Prinsip koherensi: Prinsip ini menjelaskan bahwa menggunakan gambar, kata-kata dan suara yang tidak berhubungan dapat merusak kegiatan belajar Mayer (2009, p. 167). Implikasi prinsip ini pada e-learning nantinya dengan menyesuaikan gambar, kata-kata dan suara sesuai materi, untuk menyesuaikan komposisi tersebut maka sajian materi akan lebih pada penggunaan suara dan gambar atau suara saja, dikarenakan $e$ learning ini untuk kompetensi listening pada pembelajaran bahasa Inggris. (6) Prinsip perbedaan individual: Menurut Mayer (2009, p. 235) Prinsip ini menjelaskan bahwa pengaruh desain lebih kuat bagi peserta didik berpengetahuan rendah daripada peserta didik tinggi. Implikasi prinsip ini akan diaplikasikan pada fitur kuis, dimana listening akan diukur melalui kemampuan skill lain seperti speaking dan writing.

Berdasarkan prinsip multimedia dapat disimpulkan bahwa dalam mengembangankan multimedia untuk e-learning semestinya mempunyai konten berupa teks, ilustrasi, grafik, animasi serta komposisi yang sesuai dengan materi yang disajikan. Keenam prinsip tersebut akan diimplikasikan dalam pengembangan e-learning, sehingga diharapkan e-learning yang dikembangkan sesuai dengan prinsip multimedia dan dapat meningkatkan hasil belajar serta interktivitas dalam proses pembelajaran.

Untuk mengukur kualitas produk baik dari segi materi maupun media maka perlu dilakukan evaluasi. Kemudian Alessi \& Trollip (2001, p. 549) menyampaikan bahwa dalam tes alfa hendaknya memperhatikan hal-hal sebagai berikut: (1) lingkup materi (2) informasi pendukung (3) petunjuk sikap) (4) komunikasi pengguna dengan program (5) navigasi (6) aktivitas belajar (7) fitur yang sulit dilihat (8) kehandalan (9) materi pengayaan

Sedangkan menurut Oztekin, Kong, \& Uysal (2010, p. 4) item yang perlu diperhatikan dalam menilai e-learning, yaitu: visibility, aesthetics, course management, interactivity, flexibility, consistency, reducing redundancy, error prevention, functionality, feedback and help, memorability, efficiency, accessibility.

Selain itu Surjono (2013, pp. 75-76) menyampaikan bahwa Aspek tampilan an- 
tarmuka meliputi: (a) tampilan tema; (b) layout; (c) kualitas teks; (d) kualitas gambar; (e) kualitas animasi; (f) kualitas pertanyaan; (g) kualitas navigasi; (h) konsistensi navigasi; (i) spasi. Sedangkan, aspek pedagogi metodologi meliputi: (a) interaktivitas (b) kapasitas kognitif (c) strategi pembelajaran (d) kontrol pengguna (e) kualitas pertanyaan (f) kualitas umpan balik.

Kriteria yang digunakan untuk menilai e-learning untuk aspek media, disusun ke dalam kisi-kisi instrumen dan selajutnya akan dikembangkan menjadi sebuah angket penilaian uji coba alpha dan uji beta. Aspek yang dinilai dari sisi media meliputi lima aspek yaitu, lingkup pembel-ajaran, tampilan antarmuka, pedagogi, informasi tambahan dan fitur tak tampak.

Selanjutnya beberapa aspek kriteria penilaian dari segi relevansi materi dan kesesuaian materi pembelajaran dengan pencapaian standar kompetensi dan kompetensi dasar melalui silabus yang kemudian dikembangkan dijelaskan Sudrajat (2008, p. 72) melalui beberapa indikator adalah sebagai berikut: (1) kesesuaian dengan silabus (2) kejelasan kompetensi (3) relevansi materi dengan tujuan pembelajaran (4) kebenaran materi (5) kelengkapan materi (6) penulisan materi (7) keruntutan dan kejelasan materi (8) tingkat kesulitan (9) kedalaman materi (10) kemudahan aplikasi dan contoh (11) relevansi tugas dengan materi.

Selain itu Surjono (2013, p. 75-76) men-jelaskan kisi-kisi yang bisa dijadikan contoh untuk dikembangkan menjadi butirbutir pertanyaan, yakni sebagai berikut : (1) Aspek Materi: (a) kesesuaian materi dengan tujuan pembelajaran; (b) kebenaran struktur materi; (c) keakuratan isi materi; (d) kebenaran tata bahasa; (e) kebenaran ejaan; (f) kebenaran istilah; $(\mathrm{g})$ kebenaran tanda baca; (h) kebenaran kesesuaian tingkat kesulitan dengan pengguna; (i) ketergantungan materi dengan budaya atau etnik.

Kriteria yang digunakan untuk menilai aspek untuk materi meliputi empat aspek seperti kesesuain materi, kemudahan penyampaian materi, kualitas isi materi, kualitas latihan dan test. Aspek yang dinilai oleh pengguna meliputi 15 aspek yakni, kejelasan petunjuk penggunaan e-learning, kejelasan tujuan pembelajaran, kejelasan uraian materi, keterbacan teks atau tulisan, kejelasan audio, pemberian contoh, pemberian latihan, pemberian evalusi, kejelasan petunjuk mengerjakan test, keterkaitan materi dengan evaluasi/kuis, umpan balik siswa terhadap jawaban, kejelasan bahasa, tampilan video, kebebasan memilih menu, meningkatkan minat belajar.

Berdasarkan latar belakang tersebut maka rumusan masalah pada penelitian dan pengembangan ini ialah (1) menghasilkan produk e-learning bahasa Inggris berbasis Moodle yang layak dalam peningkatan listening skill pada pembelajaran bahasa Inggris untuk SMK Negeri 4 Yogyakarta (2) mengetahui efektifitas e-learning berbasis Moodle terhadap listening skill pembelajaran bahasa Inggris siswa kelas X SMK Negeri 4 Yogyakarta .

\section{Metode Penelitian}

Metode penelitian ini mengunakan metode penelitian dan pengembangan atau disebut Research and Development ( $\mathrm{R}$ \& $\mathrm{D})$ Penelitian dan pengembangan ini bertujuan untuk mengembangkan produk e-learning bahasa Iggris dalam peningkatkan pemahaman lagu pada pembelajaran bahasa Inggris kelas X SMK

Model pengembangan yang digunakan oleh peneliti mengadopsi model pengembangan multimedia pembelajaran yang dikembangkan oleh Alessi dan Trollip (2001, p. 410). Secara umum memuat tiga proses utama yakni perencanaan (planning), perancangan (design), dan pengembangan (development).

Penelitian ini dilaksanakan pada bulan 25 Februari 2016 sampai dengan 25 Mei 2016. Penelitian dilakukan di Sekolah Menegah Kejuruan (SMK) Negeri 4 Yogyakarta. Responden penelitian dan pengembangan ini adalah siswa kelas X UPW 1 SMK Negeri 4 Yogyakarta tahun ajaran 2015/2016 semester 2. Jumlah keseluruhan responden sebanyak 31 siswa. Uji beta 
dilakukan terhadap 6 siswa, dengan penjabaran 2 siswa mewakili level tinggi, 2 siswa mewakili level sedang dan 2 siswa mewakili level rendah, penentuan level didasarkan dari aktifitas di kelas ketika observasi dan dari hasil belajar disemester sebelumnya. Sedangkan untuk test sumatif dilakukan terhadap 31 siswa kelas X UPW 1.

Prosedur pada penelitian pengembangan ini ialah sebagai berikut; (1) perencanaan meliputi: mendefinisikan bidang/ ruang lingkup, mengidentifikasi karakteristik peserta didik, membuat dokumen perencanaan, menentukan dan mengumpulkan sumber-sumber, melakukan brainstorming; (2) Perancangan meliputi: melakukan analisis konsep dan cakupan materi, membuat flowchart, mengembangkan layout, megumpulkan sumber-sumber konten, menentukan softwareyang akan digunakan; (3) Pengembangan meliputi: membangun web dengan domain dan hosting, mengembangkan konten teks, menggabungkan bagian (konten audio, video dan teks), menyiapkan materi pendukung, hingga e-learning siap untuk digunakan saat uji alfa.

Jenis data yang digunakan pada penelitian dan pengembangan ini adalah kualitatif dan kuantitatif. Data kualitatif diperoleh dari analisis kebutuhan dan wawancara pada saat dilakukan prasurvey serta hasil dari uji coba awal. Data kuantitatif diperoleh dari hasil validasi oleh ahli media dan materi serta angket motivasi belajar siswa yang dianalisis secara deskriptif dengan skala 5. Selain itu data kuantitatif diperoleh dari dari hasil pretest dan posttest.

Data-data tersebut dijadikan alat untuk mengukur kelayakan dan keefektifan produk e-elearning yang dikembangkan dalam proses pembelajaran bahasa Inggris. Selain itu data-data tersebut dijadikan bahan pertimbangan untuk merevisi produk e-learning yang dikembangkan.

Instrumen yang digunakan pada penelitian ini adalah wawancara, angket, dan tes hasil belajar. Wawancara digunakan diawal saat melakukan prasurvey untuk melakukan analisis kebutuhan. Angket digunakan untuk penilaian validasi ahli media, materi dan mengetahui respon pengguna. Tes hasil belajar digunakan untuk pretest dan posttest. Seluruh instrumen divalidasi oleh validator instrumen. Sedangkan tes hasil belajar divalidasi oleh ahli materi.

Dari data kualitatif tersebut berupa saran dan masukan dari ahli media, ahli materi serta peserta didik pada uji beta, kemudian dikumpulkan dan disimpulkan untuk memperbaiki kualitas produk yang dikembangkan. Sedangkan data kuantitatif berupa skor angket dari ahli media, ahli materi dan peserta didik yang diperoleh dari angket yang menggunakan skala likert yang dikonversikan ke dalam skala 5, yakni sangat Sangat baik, baik, cukup, kurang baik dan Tidak baik, kemudian dikonversikan menjadi nilai dalam skala 5 dengan menggunakan kriteria acuan sebagai berikut.

Tabel 1. Konversi Data Kuantitatif ke Kualitatif dengan Skala Lima

\begin{tabular}{cll}
\hline Nilai & Interval Skor & Kategori \\
\hline 1 & $5>4,22$ & Sangat Baik \\
2 & $4,21-3,41$ & Baik \\
3 & $3,40-2,61$ & Cukup \\
4 & $2,60-1,79$ & Kurang \\
5 & $<1,79$ & Sangat Kurang \\
\hline
\end{tabular}

\section{Hasil Penelitian dan Pembahasan}

Hasil penelitian dan pengembangan ini adalah e-learning untuk pembelajaran bahasa Inggris. Tampilan awal e-learning disajikan pada Gambar 1.

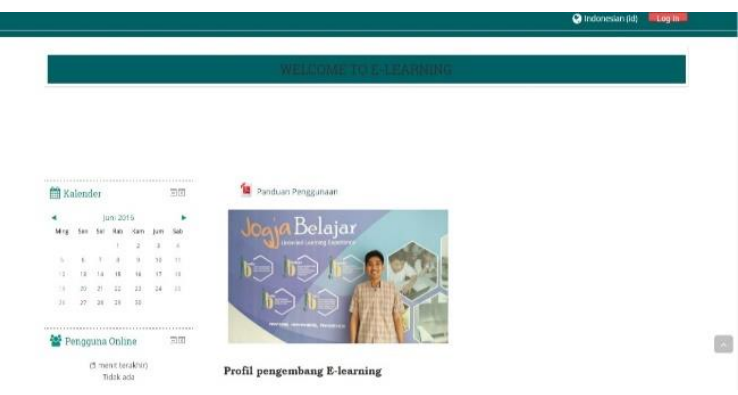

Gambar 1. Tampilan Awal E-Learning

Aplikasi yang digunakan dalam pengembangan ialah Learning Managemen System ( LMS) Moodle versi 3. Keunggulan produk e-learning dibandingkan e-learning 
lain ialah pada sisi aktivitas berupa kuis dan tugas, pada sisi kuis dan tugas peserta didik secara langsung melatih keterampilan berbahasa mereka seperti listening dan speaking. Pada aktivitas listening aktivitas yang dilakukan ialah peserta didik menyimak audio sambil mengisi teks rumpang. Sedangkan untuk aktivitas speaking peserta didik diminta untuk merekam suara mereka, berkaitan dengan informasi dan pesan dari audio. Adapun aktivitas tersebut sebagaimana disajikan pada Gambar 2 dan Gambar 3.

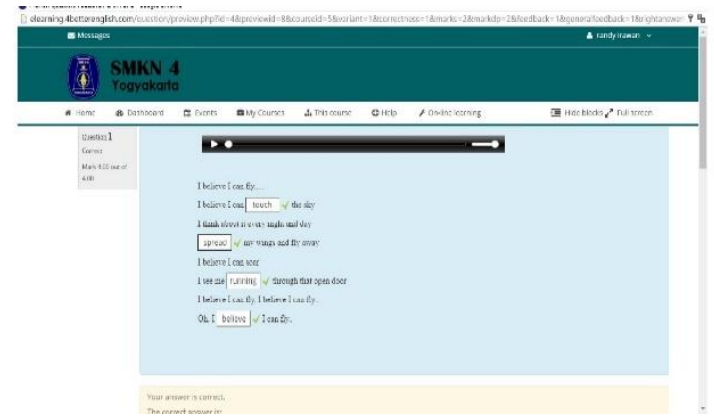

Gambar 2. Tampilan Aktivitas Listening

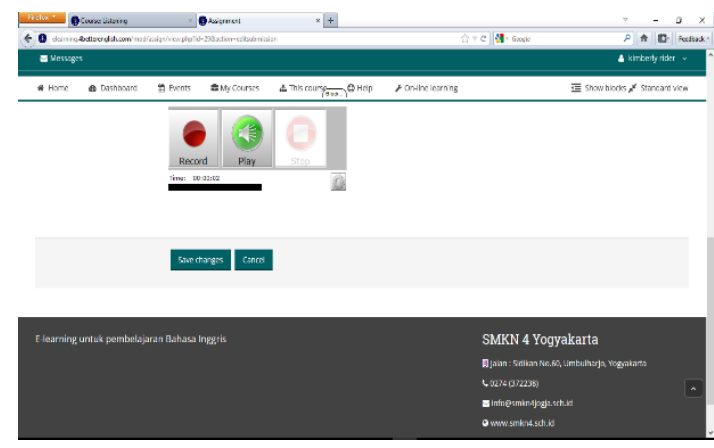

Gambar 3. Tampilan Aktivitas Speaking

Setelah produk selesai dikembangkan, kemudian divalidasi oleh 2 ahli materi dan 2 ahli media. Tujuan proses validasi ahli materi adalah untuk mengukur tingkat kevalidan dan kelayakan materi dalam e-learning, materi yang disajikan dalam e-learning ialah menagkap makna dan informasi dari song. Secara umum ada empat aspek yang divalidasi oleh ahli materi yakni aspek kesesuaian materi, aspek kemudahan penyampaian isi, aspek kualitas isi materi dan kualitas latihan dan test.

Adapun hasil validasi dari ahli materi seperti pada Gambar 4.

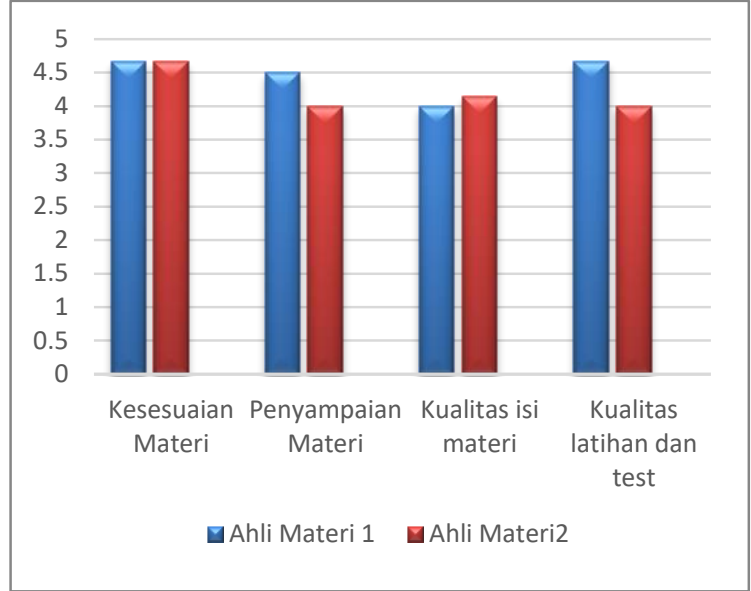

Gambar 4. Hasil Validasi Materi

Berdasarkan analisis terhadap data dan persentase hasil penilaian ahli materi diketahui bahwa 4 kategori kualitas e-learning berbasis Moodle pada pembelajaran bahasa Inggris kompetensi listening termasuk kategori "Sangat baik" dengan rerata skor 4,34 .

Selanjutnya melakukan validasi media yang bertujuan untuk mengukur tingkat kelayakan media yang dikembangkan sebelum digunakan pada tahap pengembangan selanjutnya. Kedua ahli media diberikan instrumen untuk menilai kualitas media secara keseluruhan. Validasi media diturunkan menjadi lima aspek. Pertama aspek lingkup pembelajaran, kedua tampilan antarmuka, ketiga pedagogy, keempat informasi tambahan dan kelima fitur tak tampak. Hasil validasi ahli media sebagaimana Gambar 5 berikut.

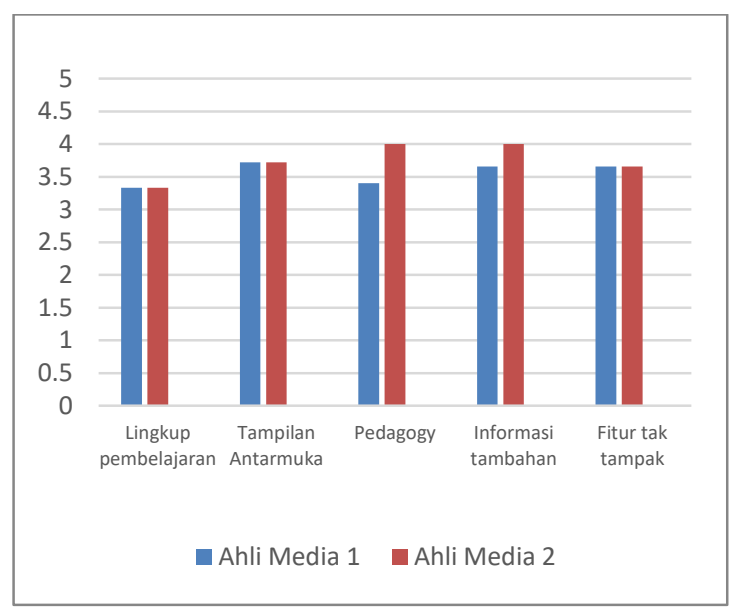

Gambar 5. Hasil Validasi Ahli Media 
Berdasarkan analisis terhadap data dan persentase hasil penilaian ahli materi diketahui bahwa kualitas e-learning berbasis Moodleuntuk pembelajaran bahasa Inggris kompetensi listening untuk SMK Negeri 4 Yogyakarta termasuk kategori "Baik" dengan rerata skor 3,70.

Selanjutnya pada tahap uji beta dilakukan terhadap 6 peserta didik, keenam peserta didik tersebut digolongkan kepada 3 level kemampuan, 2 dengan kemampuan level tinggi, 2 dengan kemampuan level sedang dan 2 dengan level kemampuan rendah.

Pada uji beta terdapat 15 aspek yang akan dinilai berkaitan dengan kualitas elearning dan kelayakan materi, 15 aspek tersebut ialah, kejelasan petunjuk penggunaan e-learning, kejelasan tujuan pembelajaran, kejelasan uraian materi, keterbacan teks atau tulisan, kejelasan audio, pemberian contoh, pemberian latihan, pemberian evalusi, kejelasan petunjuk mengerjakan tes, keterkaitan materi dengan evaluasi/kuis, umpan balik siswa terhadap jawaban, kejelasan bahasa, tampilan video, kebebasan memilih menu, meningkatkan minat belajar. Berdasarkan hasil analisis diperoleh rata-rata 4,30 dan termasuk kategori "Sangat baik". Adapun hasil beta dari uji beta ialah sebagaimana pada Gambar 6.

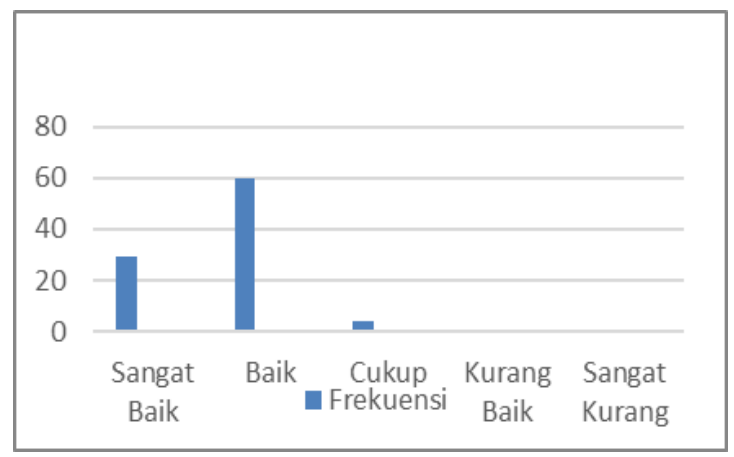

Gambar 6. Hasil Uji Beta

Tes sumatif dilakukan terhadap 31 peserta didik kelas $X$ jurusan Usaha Perjalanan Wisata (UPW) SMK Negeri 4 Yogyakarta. Evaluasi sumatif dilakukan melalui pretest dan posttest. Data pretest dan posttest kemudian dibandingkan untuk mengetahui signifikansi peningkatan hasil belajar antara pretest dan posttest sebelum dan sesudah menggunakan program yang dikembangkan. Adapun data tabel perbandingan hasil pretest dan posttest dapat dilihat pada Tabel 2.

Tabel 2. Perbandingan Hasil Pretest dan Posttest

\begin{tabular}{ccc}
\hline Variabel & Pretest & Posttest \\
\hline Nilai Terendah & 72,5 & 92,5 \\
Nilai Tertinggi & 90 & 100 \\
Rata-rata & 78,94 & 96,13 \\
Gain & 17,19 & \\
\hline
\end{tabular}

Berdasarkan analisis data pretest dan posttest yang dapat diketahui bahwa terjadi peningkatan hasil belajar sebesar 17,19 \% pada siswa kelas X UPW 2 SMK Negeri 4 Yogyakarta sebagai peserta uji coba e-learning berbasis Moodle.Hasil dari evaliasi sumatif dapt dilihat pada gambar 7 .

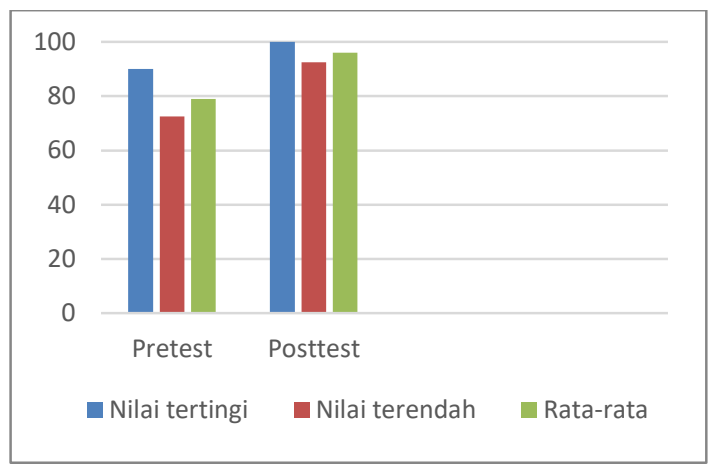

Gambar 7. Hasil Tes Sumatif

\section{Simpulan}

Berdasarkan hasil analisis data dan pembahasan dapat disimpulkan bahwa produk e-learning berbasis Moodle dalam peningkatan pemahaman lagu pembelajaran bahasa Inggris untuk siswa SMK kelas $X$ efektif dalam meningkatkan hasil belajar, hasil dari penelitian dan pengembangan berupa produk e-learning berbasis Moodle untuk meningkatkan meningkatkan kemampuan listening pada pembelajaran bahasa Inggris untuk siswa SMK kelas $X$ yang dapat diakses melalui elearning4betterenglish. com. Software yang digunakan untuk me- 
ngembangkan e-learning ini menggunakan Moodle versi 3.1 dengan menambahkan plugins Poodll dan Audio online sedangkan fitur Moodle yang digunakanberupa forum, chat, materi, dan Quiz dan tugas. Kegiatan pembelajaran menggunakan e-learning ini dapat dilakukan dengan cara tatap muka dan jarak jauh (online).

Kelayakan produk e-learning berbasis Moodlemeningkatkan kemampuan listening pada pembelajaran bahasa Inggris untuk siswa SMK kelas X berdasarkan hasil uji alpha melalui validasi oleh ahli materi 1 diperoleh rata-rata penilaian sebesar 4,60 dengan kategori "Sangat Baik" dan validasi oleh materi 2 diperoleh rata-rata penilaian sebesar 4,08 dengan kategori "Baik".

Hasil uji alfa melalui validasi oleh ahli media 1 diperoleh rata-rata penilaian yakni 3,60 dengan kategori "Baik" dan validasi oleh ahli media 2 diperoleh rata-rata penilaian 3,80 dengan kategori "Baik".

Sedangkan hasil uji beta melalui validasi oleh pengguna e-learning diperoleh rata-rata penilaian sebesar 4,30 dengan kategori "Sangat Baik". Hasil evaluasi sumatif terhadap penggunaan e-learning berbasis Moodle untuk meningkatkan kemampuan listening pada pembelajaran bahasa Inggris SMK kelas $X$ menunjukan bahwa terdapat peningkatan pencapaian hasil belajar siswa sebesar $17,19 \%$. Nilai rata-rata pretest 78,94 meningkat pada posttest menjadi 96,13 dengan presentase ketuntasan belajar siswa $100 \%$.

Dari hasil penelitian yang dilakukan menunjukan bahwa keterampilan listening dalam hal pemahaman lagu dapat ditingkatkan dengan e-learning.

Penelitian ini telah membuktikan bahwa pengembangan e-learning efektif dapat meningkatkan kemampuan listening dalam hal pemahaman isi lagu, dimana hal tersebut sejalan dengan beberapa definisi $e$ learning yang bertujuan untuk meningkatkan pengetahuan dan keterampilan peserta didik dimana hal tersebut sejalan dengan beberapa definisi e-learning yang bertujuan untuk meningkatkan pengetahuan dan keterampilan peserta didik. E-learning dapat diimplementasikan secara synchronous, asynchronous atau campuran keduanya, dalam penelitian ini implementasi tersebut dilakukan dengan campuran keduanya yakni penggabungan on-line dan konvensional hal ini dilakukan agar peningkatan hasil belajar dapat selalu dipantau peningkatanya, peningkatan hasil belajar pada penelitian ini ialah sebesar 17,19\%.

Implikasi yang berkaitan dengan teori keterampilan menyimak atau listening, penelitian ini membuktikan bahwa listening skill berbeda dengan hearing (mendengarkan), listening ialah proses menyadikan hingga proses dimana memahami apa yang didengarkan, hal ini sejalan dengan hasil penelitian ini dimana listening memberikan peningkatkan pemahaman isi lagu dalam mengidentifikasi makna dan informasi yang terkandung didalam lagu, dalam hal yang lebih spesifik listening membantu dalam pemhaman unsur kebahasaan seperti kosa kata dan menentukan singular dan plural.

Hasil penelitian ini memberikan implikasi pada penyelenggara pendidikan dalam hal ini khususnya SMK Negeri 4 Yogyakarta dan penyelengara pendidikan lain dalam proses pembelajaran bahasa Inggris di sekolah. Dari hasil penelitian menunjukkan bahwa pembelajaran dengan e-learning mampu meningkatkan hasil belajar bahasa Inggris kompetensi skill listening sehingga dapat dikemukakan bahwa e-learning memberikansumbangsih terhadap peningkatan hasil belajar peserta didik jurusan UPW kelas X di SMK Negeri 4 Yogyakarta pada kompetensi listening, sehingga pembelajaran dengan e-learning dapat dijadikan alternatif dalam pembelajaran.

Dengan kemajuan teknologi dan komunikasi internet dalam dunia pendidikan telah mendukung sistem pendidikan dalam bentuk e-learning. Dengan sistem pendidikan tersebut memungkinkan pemerataan pendidikan di Indonesia, mengingat Indonesia ialah negara kepulauan yang sangat luas, e-learning dapat menyediakan pendidikan yang dapat diakses oleh orang banyak kapan saja dan dimana saja, meskipun dalam proses implikasi ini juga perlu mem- 
perhatikan beberapa hal lain seperti budget dan infrastruktur.

Sehingga kedepan e-learning ini dapat menjadi inovasi dalam pembelajaran bahasa Inggris khususnya pada keterampilan listening,dimana pada keterampilan listening membutuhkan media.

\section{Daftar Pustaka}

Alessi, S. M., \& Trollip, S. P. (2001). Multimedia for learning: methods and development (3rd ed.). Boston: Allyn and Bacon.

Banasuru, A. (2013). Filsafat dan filsafat ilmu. Bandung: Alfabeta.

Chen, Y. (2013). The impact of intergrating technology and social experience in the college foreign language classroom. The Turkish Online Journal of Educational Technologyurkish Online Journal of Educational Technology (TOJET), 12(3). Retrieved from http://www.tojet.net/articles/v12i3/ 12315.pdf

Clark, R. C., \& Mayer, E. R. (2008). Elearning and the science of instruction: provenguidelines for consumers and designers of multimedia learning (3rd ed.). San Francisco: Pfeiffer.

Darmawan, D. (2014). Pengembangan elearning: teori dan desain. Bandung: Rosda.

Horton, W. (2001). E-learning by design. San Fransisco: Pfeiffer.

Iskandarwassid, I., \& Sunendar, D. (2015). Startegi pembelajaran bahasa. Bandung: Rosda Karya.

Jati, G. (2013). Learning management system (Moodle) and e-learning content development. Jurnal Sosioteknologi, 12(28), 277-289. https:/ / doi.org/10.5614/sostek.itbj.20 13.12.28.3

Mayer, R. E. (2009). Multimedia learning prinsip-prinsip dan aplikasi. (T. W. Utomo, Trans.). New York: Cambrigde University Press.

Oztekin, A., Kong, Z. J., \& Uysal, O. (2010). UseLearn: A novel checklist and usability evaluation method for eLearning systems by criticality metric analysis. International Journal of Industrial Ergonomics, 40(4), 455-469. https://doi.org/10.1016/j.ergon.2010. 04.001

Renukadevi, D. (2014). The role of listening in language acquisition; the challanges \& startegies in teaching listening. International Journal of Education and Information Studies, 4(1), 60. Retrieved from http://www.ripublication.com/ijeisv 1n1/ijeisv4n1_13.pdf.

Riyanto, S. (2015). The practice of teaching english. Yogyakarta: Penerbit Andi.

Rosenberg, M. J. (2001). E-learning strategies for delivering knowledge in the digital era. New York, NY: McGraw Hill.

Sudrajat, A. (2008). Pengertian pendekatan, strategi, metode, teknik dan model pembelajaran. Bandung: Sinar Baru Algensindo.

Surjono, H. D. (2013). Membangun bourse elearning berbasis Moodle. Yogyakarta: UNY Press. 